\title{
Dilemma in Handling Corpse with COVID-19 Protocol at Hospital in Padang, West Sumatera (Indonesia)
}

Noverika Windasari ( $\nabla$ windasari@med.unand.ac.id)

Department Forensic and Medico-legal, Medical Faculty, Universitas Andalas

Citra Manela

Department Forensic and Medico-legal, Medical Faculty, Universitas Andalas

Fatimah Azahra Zetta

Medical Faculty, Universitas Andalas

\section{Research Article}

Keywords: Covid-19, handling corpse, protocol, mortuary staff

Posted Date: October 23rd, 2020

DOI: https://doi.org/10.21203/rs.3.rs-96982/v1

License: (c) (i) This work is licensed under a Creative Commons Attribution 4.0 International License.

Read Full License 


\section{Abstract}

Background: The high risk of transmitting Covid-19 from the corpse causes the importance of handling protocols under coronavirus characteristics. Indonesian Forensic Doctor Association (PDFI) recently published a guideline to deal with this situation. Hospitals in Indonesia adapted these instructions as the standard. This process faces some struggle situations since this new guidance different from the usual protocols that are already well known by people in handling the deceased. This research evaluates the implementation of these protocols by medical practitioners in West Sumatera. This descriptive research was conducted in two COVID-19 refferal Hospital in Padang. There are 13 mortuary staffs as respondents from both hospitals who directly deal with the corpses. There were 129 bodies served under Covid-19, the guideline during this period.

Results: The mortuary staff comes to the isolation room in about 30 minutes after being called to handling the corpse. Corpses were prepared and packed in this room. The dead bodies were transferred to the mortuary room before being driven to the funeral location by ambulance. The corpse, on average, waited less than 3 hours in the mortuary room. Mortuary staff showed a full sincerity to avoid transmitting Covid-19 as all of them used the recommended Personal Protective Equipment (PPE) while handling the infected corpses. The staff only started their work after the standard tools are available. Mortuary staff reported that $40 \%$ of relatives of the deceased gave a negative response to the Covid- 19 guidelines.

Conclusion: The implementation of the procedure to follow the instruction from PDFI in handling infected bodies has some problems. The process could be delayed if the protective equipment runs out, so the staff should wait for the availability PPE. The number of ambulances also gained the time process because some bodies remained so long for the available transport. Although the mortuary staff showed serious concern on the guidelines, they feel unsupported since some families of deceased show negative respect to the protocols. This research recommended that massive education about the Covid-19 protocol in preparing and packing the infected bodies is essential not only for medical practitioners but also for citizens.

\section{Background}

Coronavirus disease 2019 (COVID-19), caused by SARS-CoV-2 that become current global outbreak, was first detected in Wuhan, China, in December 2019. ${ }^{1}$ SARS-CoV-2 can transmit in the environment and can be detected outside the host. A study showed that SARS-CoV-2 still viable in aerosol in 3 hours and stable on surfaces until 72 hours. ${ }^{2}$ Moreover, another study declared that SARS-CoV-2 RNA found in cabin's of infected people up to 17 days. ${ }^{3}$

The transmission of SARS-CoV-2 through the handling corpses is still no information. A high potential risk threat mortuary staff because of handling corpses with suspected or confirmed COVID-19, which is related to direct contact with deceased body or body fluid. ${ }^{4}$ How long COVID-19 can be detected in body 
fluid of corpse is unknown. A study reported that nasopharynx swab and oropharynx swab could still detect this virus 27 hours postmortem. Minimizing the contact with infected and/or suspected deceased is necessary to avoid transmitting. ${ }^{5}$ Mortuary staff need clear guidance to maintain a standard process during the work. Hospitals in Indonesia follow the procedures for handling corpse published by Indonesian Forensic Doctor Association. ${ }^{6}$ This research evaluates the implementation of these protocols by medical practitioners and the public in West Sumatera, Indonesia.

\section{Methods}

This was a descriptive research that was conducted in 2 COVID-19 referral hospitals in Padang, Sumatera Barat. The program was implemented from March to July 2020. Data were obtained by providing questionnaire to all mortuary staff involved in handling corpses by COVID-19 protocol in both Hospitals. The questionnaire consisted of several questions related to the process of handling COVID-19's body, starting from the patient being declared passed away to transported with ambulans to the grave. The ethical approval was requested to the Hospital research ethics committee.

\section{Result}

Total respondents were 13 mortuary staff, consisted of 10 staff from $1^{\text {st }}$ refferal hospital and 3 staff from $2^{\text {nd }}$ refferal hospital. 69,2\% (9 respondent) mortuary staff were male and 30,8\% (4 respondent) were female. There were 129 bodies served with Covid-19 protocol during this period. All the protocols in both Hospitals were complied with Indonesian Guidelines of handling corpse with COVID-19 protocol.

All mortuary staff $(100 \%)$ were used Personal Protective Equipment (PPE) standard when handling corpses with COVID-19 protocol. The PPE that they used were head cap, gown, apron, medical mask, googles/face shield, long gloves, boot, and shoe cover. Figure 1 described PPE's availability in mortuary room from both hospital. When the PPE runs out, mortuary staff will ask to isolation logistic room for availability PPE stocks (other room/unit).

Mortuary staff handling the body in an isolation room. In isolation room, mortuary staff will close the body holes and wound, disinfect the body with chlorine, bath or "tayamum" (for Moeslim), and wrap the body sequentially with plastic - shroud - plastic - and body bag. After packing the body, then the corpses were transported to mortuary room. In mortuary room, the deceased will put in sealed coffin, prayed and transit before transported to the grave. The whole process of handling corpse with Covid-19 protocol in both hospital can be seen in figure 2 .

It took mortuary staff an average of 30 minutes $(61,5 \%$ respondent) to arrive in isolation room since mortuary staff had information from isolation room that there was a dead body need handling with Covid-19 protocol. This time may be longer related to the availability PPE in mortuary room, limited number of mortuary staff, or the staff still in other duty. 
The average time for corpses transit in the mortuary room was less than 3 hours. Some of obstacles that have been encountered by mortuary staff which could make the transit time longer are related to coordination transportation from local health office for burial, waiting for certainty of burial locations, coordination with families who reject the Covid- 19 protocol, and request from family members.

Table 1. Average response time of mortuary staff in using Covid-19 protocol.

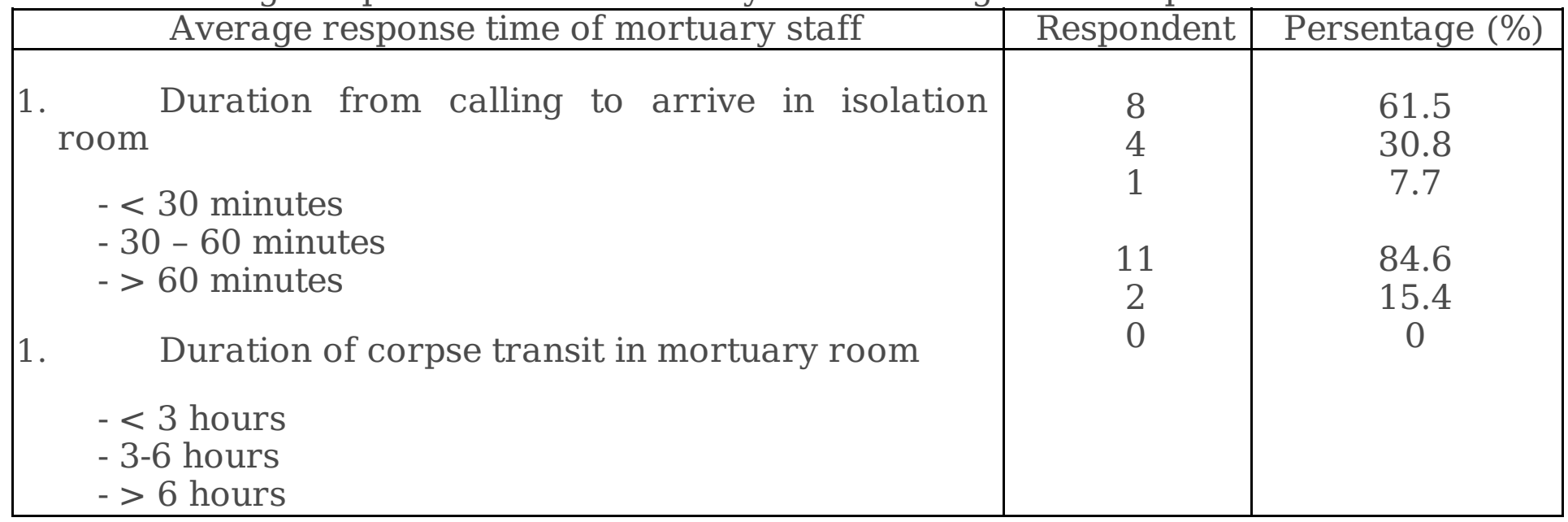

According to respondents, response of corpse family to Covid-19 protocol was neutral (23\%) and very bad $(23 \%)$. Figure 3 described family response received by mortuary staff when handling corpse with Covid19 protocols.

\section{Discussion}

It is very important for mortuary staff followed the hospital protocol in handling deceased with Covid-19. WHO declared that corpse with COVID-19 should use a leak-proof body bag to limiting contact with corpse body fluid. ${ }^{5}$ Several country that follows this guideline are China, USA, UK, Australia, Germany, India, and also Indonesia. ${ }^{6-14}$ Both hospital corpse's protocol were suitable with WHO and Indonesian Forensic Doctor Association guidelines.

Personal Protective Equipment (PPE) which used by hospital mortuary staff in Padang had been appropriate with minimum standard PPE that recommended by Indonesian Ministry of Health.The minimum standard PPE that recommended for handling corpse without autopsy are nitrile gloves, long waterproof gown, face shield or goggles, medical mask, shoe protector, and head protector. ${ }^{15}$

There are many religious organizations in Indonesia have declared a statement regarding the handling of Covid-19 body for their followers, like Moeslims, Protestant, Catholics, Hindus, and Buddhists. There statement showed agreement about the process of handling body based on protocols established by the hospital or the government. ${ }^{16-18}$ Although standard operational procedure of handling corpse using COVID-19 protocols have been supported by religious organization (Muslim and non-Muslim), this process faces some struggle situations since this new guidance different from the usual protocols that already well known by people in handling deceased. It was proved by $40 \%$ corpse family responses were 
bad and very bad about implementation of corpse's handling with COVID-19 protocols. The negatives responses also related to duration of corpse transit that be longer.

\section{Conclusions}

The procedure of handling infected bodies from PDFI is well followed by mortuary staff in Padang City. However, this is not a common procedure in handling corpses, there were some problems. The process could be delayed if the protective equipment runs out, so the staff should wait for the availability of PPE. The number of ambulances also gained the time process because some bodies remained so long for the available transport. Although the mortuary staff showed serious concern on the guidelines, they feel unsupported since some families of the deceased show negative respect to the protocols. This research recommended that massive education about the Covid-19 protocol in preparing and packing the infected bodies is essential not only for medical practitioners but also for citizens. It can minimize family rejection about the Covid-19 deceased protocol. Moreover, good coordination about deceased transport and funeral process between hospital and public health office is very important. Gaining the public knowledge about protocol of Covid-19 hoped can reduce the negative response to this procedure.

\section{Abbreviations}

PDFI: Indonesian Forensic Doctor Association

PPE: Personal Protective Equipment

\section{Declarations}

\section{Ethics approval and consent to participate}

The ethical approval was requested to the research ethics committee of M. Djamil Padang Hospital with ethical approval number 219/KEPK/2020.

Informed consent were obtained from respondents by filling the form (in written).

\section{Consent for publication}

Not applicable

\section{Availability of data and material}

The raw data available with one of the authors (NW)

\section{Competing interests}

The author declares that there are no competing interests. 


\section{Funding}

This research was funded by Faculty of Medicine of Universitas Andalas as beginner lecturer schemes research contract No. 14/UN.16.02/DP/PT.01.03/2020.

\section{Authors' contributions}

NW and CM conceived of the presented idea. NW developed the theory and performed the computations. NW and CM verified the analytic methods. CM encouraged FA to investigate and supervised the findings of this work. All authors discussed the results and contributed to the final manuscript.

\section{Acknowledgements}

The authors thanks Universitas Andalas for providing the grant and all mortuary staff of M Djamil hospital and Andalas hospital for participating in this research

\section{References}

1. World Heath Organization. 2020. Rational Use of Personal Protective Equipment for Coronavirus Disease2019 (COVID-2019): Interim Guidance. February 27, 2020.

2. Doremalen N, et al (2020) Aerosol and Surface Stability of SARS-CoV-2 as Compared with SARSCoV-1. The New England Journal of Medicine. https://doi.org/ 10.1056/NEJMc2004973.

3. Moriarty LF, et al. 2020. Public Health Responses to COVID-19 Outbreaks on Cruise Ships Worldwide, February - March 2020. Morbidity and Mortality Weekly Report. March 2020, Vol. 69(1). P 347-351.

4. European Centre for Disease Prevention and Control. 2020. Consideration Related to the Safe Handling of Bodies of Deceased Person with Suspected or Confirmed COVID-19.

5. Dijkhuizen LGM, Gelderman HT, Duijst WLJM. 2020. Review: The Safe Handling of A Corpse (SUSPECTED) with COVID-19. Journal of Forensic and Legal Medicine 73. P 1-5.

6. Persatuan Dokter Forensik Indonesia. 2020. Panduan Penatalaksanaan Jenazah Suspek COVID-19.

7. Precautions for Handling and Disposal of Dead Bodies, Hong Kong, China; 2020. Available on: https://www.chp.gov.hk/files/pdf/grp-guideline-hp-ic-precauti ons_for_handling_and_disposal_of_dead_bodies_en.pdf. March 15th, 2020.

8. Collection and Submission of Postmortem Specimens from Deceased Persons with Known or Suspected COVID-19, March 2020 (Interim Guidance). United States of America; 2020. https://www.cdc.gov/coronavirus/2019-ncov/hcp/guidance-pos 
9. Guidance COVID-19: Epidemiology, Virology and Clinical Features. United Kingdom; 2020. Available on: https://www.gov.uk/government/publications/ wuhan-novel-coronavirus-backgroundinformation/wuhan-novel-coronavirus-epidemiology-virology-and-clinical-features. March 15th, 2020. 14.

10. Guidance COVID-19: Infection Prevention and Control (IPC), United Kingdom; 2020. Available on: https://assets.publishing.service.gov.uk/government/uploads /system/uploads/attachment_data/file/874316/Infection_prevention_and_control_ guidance_for_pandemic_coronavirus.pdf. March 15th, 2020.

11. Hanley B, Lucas SB, Youd E, et al. 2020. Autopsy in suspected COVID-19 cases. J Clin Pathol;73:239-242.

12. COVID-19 - Handling of Bodies by Funeral Directors, Australia; 2020. Available on: https://www.health.nsw.gov.au/Infectious/factsheets/Pages/covid-19-fun eral-directors.aspx. March 15th, 2020.

13. Keten D, Okdemir E, Keten A, et al. 2020. Covid 19 and protection precautions to Be considered in postmortem transactions. J Forensic Legal Med. In press.

14. DGHS/MOHFW. 2020. COVID-19: Guidelines on Dead Body Management, India. Available on: https://www.mohfw.gov.in/1584423700568_COVID19

15. Wibowo B, et al. 2020. Petunjuk Teknis Alat Pelindung Diri (APD) dalam Menghadapi Wabah COVID19. Direktorat Jenderal Pelayanan Kesehatan Kementerian Kesehatan Republik Indonesia. P 25-26.

16. Surat Edaran Parisada Hindu Dharma Indonesia Pusat No. 312/SE/PHDI Pusat/III/2020. Pedoman Perawatan Jenazah dan Upacara Pitra Yajna Bagi Jenazah Pasien COVID-19.

17. Persekutuan Gereja-Gereja di Indonesia. Panduan Pelayanan dan Ibadah Perkabungan Warga Gereja Positif COVID-19. March 24, 2020. Di unduh dari https://pgi.or.id/panduan-pelayanan-dan-ibadahperkabungan-warga-gereja-positif-covid-19/

18. Fatwa Majelis Ulama Indonesia No. 18 Tahun 2020 tentang Pedoman Pengurusan Jenazah (Tajhiz Al-Jana'iz) Muslim yang Terinfeksi COVID-19. Diunduh dari https://mui.or.id/produk/fatwa/27752/fatwa-no-18-tahun-2020-pedoman-pengurusan-jenazahtajhiz-al-janaiz-muslim-yang-terinfeksi-covid-19/

\section{Figures}




\section{Experience of staff \\ run out PPE}

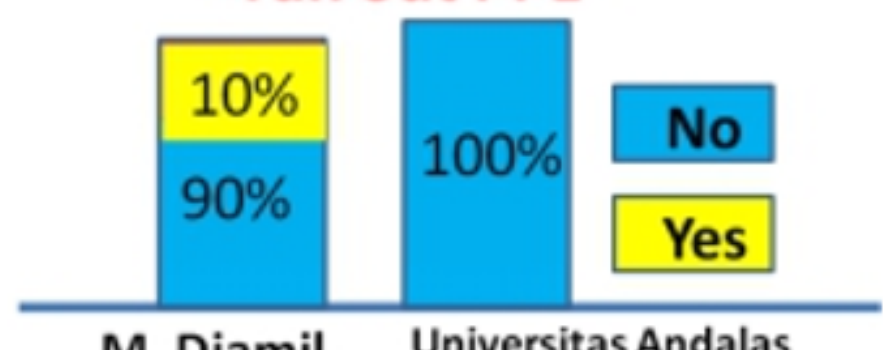

M. Djamil Universitas Andalas

\section{Figure 1}

Availability PPE in mortuary room at two COVID-19 referral hospitals in Padang.

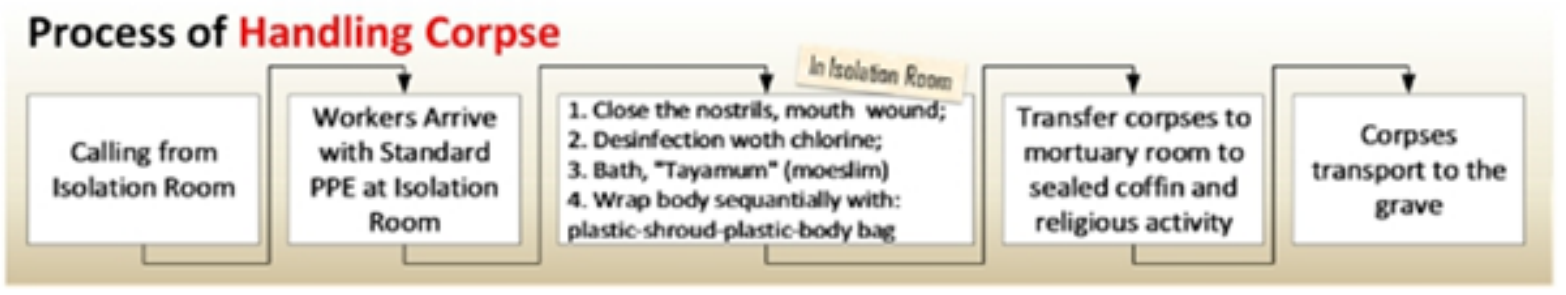

Figure 2

Process of handling corpse with COVID-19 protocol in two COVID-19 referral hospital in Padang. 


\section{Response of Corpses' Family to Covid-19 Protocol}

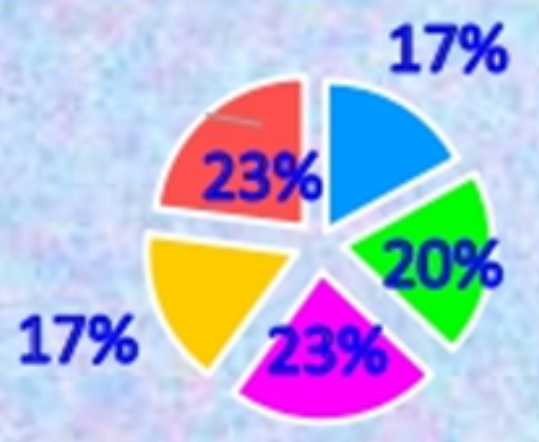

\section{$\square$ Very good $\square$ Good $\square$ neutral $\square$ bad $\square$ Very bad}

Figure 3

Family response that received by mortuary staff about Covid-19 protocols. 